\title{
The impact of antiretroviral therapy on HPV and cervical intraepithelial neoplasia: current evidence and directions for future research
}

\author{
Lara F Bratcher ${ }^{1}$ and Vikrant V Sahasrabuddhe*2
}

\begin{abstract}
Increasing numbers of human immunodeficiency virus (HIV)-infected women are now accessing life-prolonging highly active antiretroviral therapy (HAART) in developing countries. There is a need for better understanding of interactions of human papillomavirus (HPV) and HIV, especially in the context of increasing life expectancy due to HAART. The data regarding the impact of HAART on reducing the incidence and progression and facilitating the regression of HPV infection and cervical abnormalities is largely inconsistent. Published studies differ in their study designs (prospective or retrospective cohorts or record linkage studies), screening and diagnostic protocols, duration and type of HAART use, recruitment and referral strategies, and definitions of screening test and disease positivity. Due to the ethical and resource limitations in conducting randomized trials of the impact of HAART on incidence of HPV, CIN, and cervical cancer among HIV-infected women, it is important to consider innovative study designs, including quasi-experimental trials and operations research in sentinel populations to answer the critical research questions in this area.
\end{abstract}

\section{Background}

Invasive cervical cancer (ICC), although entirely preventable by early detection and treatment, remains one of the most common malignancies among women worldwide[1]. ICC and its precursor, cervical intraepithelial neoplasia (CIN), are associated with persistent infection with oncogenic 'high-risk' (HR) types of the human papillomavirus (HPV). Products of HPV oncogenes E6 and E7 alter normal genetic and cellular functions and induce malignant transformation. In women with healthy immune systems, most HPV infections are cleared. However, for those with persistent HR-HPV infection, gradual accumulation of altered cellular genetic material may progress, leading to development of CIN (grades 1, 2, 3) and eventually ICC. These changes tend to originate at the squamocolumnar junction of the cervix and may increasingly involve surrounding cells. Characteristic changes in cervical cells throughout this progression can be detected at the pre-clinical stage, allowing for treatment of precursor lesions long before ICC occurs.

\footnotetext{
* Correspondence: vikrant.sahasrabuddhe@vanderbilt.edu

2 Institute for Global Health and Department of Pediatrics, Vanderbilt University School of Medicine, Nashville, USA

Full list of author information is available at the end of the article
}

The developing world carries the largest burden (over $80 \%$ ) of ICC, largely as a result of the expense and logistical challenges in establishing and sustaining populationlevel screening and treatment programs. (Figure 1) In many resource-limited areas, it is the most common cause of death from malignancies in women[1]. Those same areas also carry a large burden of human immunodeficiency virus (HIV) and acquired immunodeficiency syndrome (AIDS) (Figure 2). HIV-infected women face an increased risk for the incidence, $[2,3]$ persistence, $[4,5]$ and recurrence $[6,7]$ of HPV-induced anogenital and cervical neoplastic disease[8]. Although ICC has been labeled an AIDS-defining malignancy, there is still a limited understanding of the natural history and epidemiology of HPV-induced neoplastic disease in HIV-infected women.

The introduction of highly active antiretroviral therapy (HAART*) in the late nineties resulted in dramatic improvement of clinical outcomes and life expectancies for people living with HIV/AIDS. It also gave hope that improved immunological status would result in better clearance of HPV infection in HIV-infected women, much like other opportunistic and AIDS-associated infections, and result in a gradual decrease in the inci- 


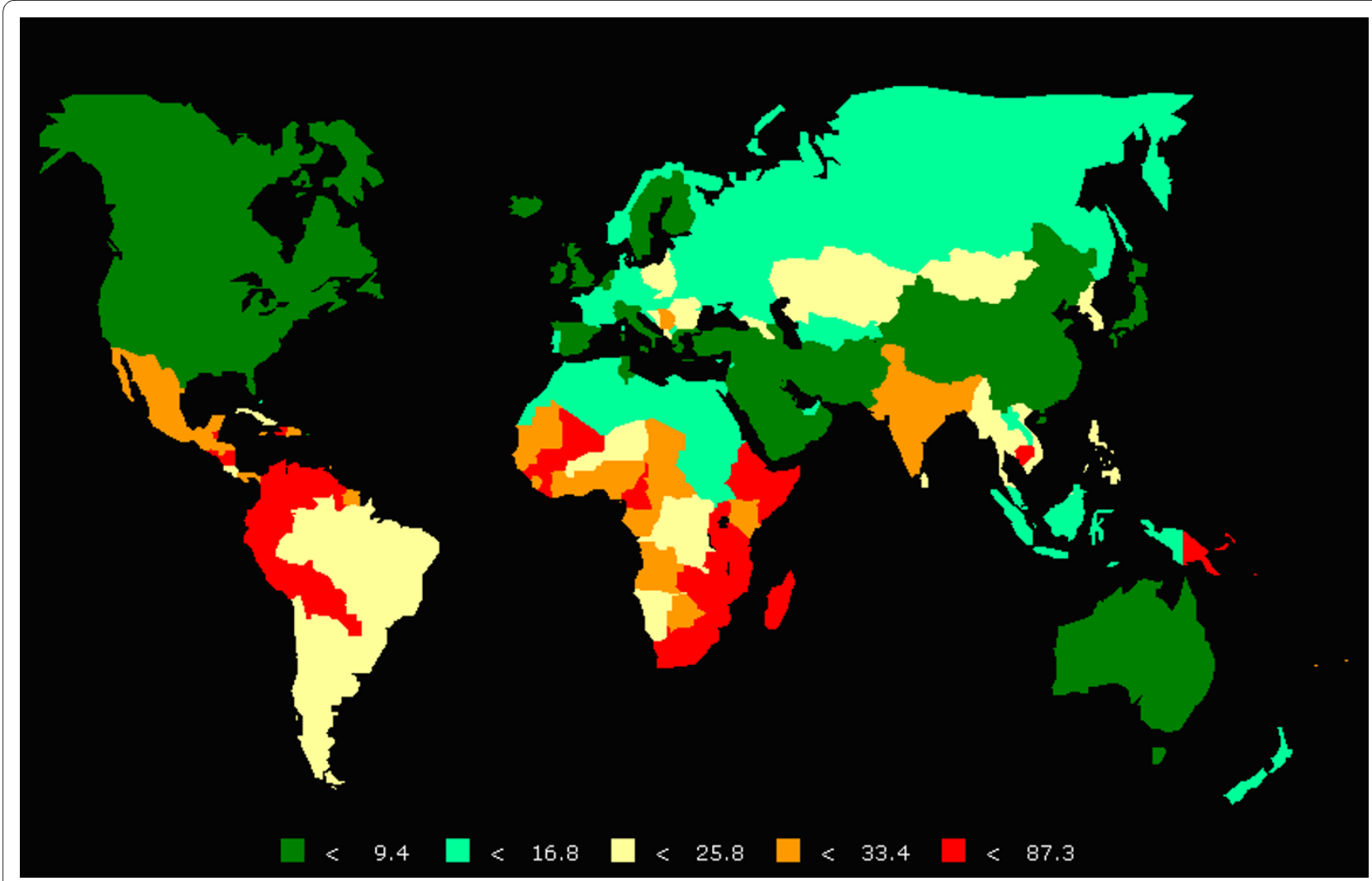

Figure 1 Global cervical cancer age-standardized incidence rate per 100,000 women (2002) [Source: International Agency for Research on Cancer: Cancer Mondial: http://www-dep.iarc.fr].

dence and progression of cervical neoplasia. However, data from the industrialized world does not point to a clear reduction in the burden and severity of cervical disease with introduction of HAART, in contrast to other AIDS-related malignancies, most notably Kaposi's sarcoma and non-Hodgkin lymphoma [9-12].

The need for better understanding of the interactions between HIV and HPV in the context of HAART is therefore even more pressing as increasing numbers of HIVinfected women are living longer with a persistent risk of ICC. Guidelines for prevention and treatment strategies for cervical cancer among HIV-infected women are largely based on limited evidence, or in the case of resource limited settings, are completely lacking. In this review, we summarize the available epidemiological evidence in this area, nearly all of which originates from industrialized nations. We discuss the priorities for further research in relation to resource-limited settings, home to over $90 \%$ of women living with HIV/AIDS.

\section{Methods}

A systematic review of literature documenting the impact of HAART on development of HPV-induced cervical intraepithelial neoplasia (CIN) in HIV-infected women was conducted using PubMed. Article selection criteria included any clinic-based observational or populationbased linkage studies documenting both HAART status and HPV/CIN/ICC rates. PubMed was searched with an end date of January 2009 using Medical Subject Headings (MeSH) "Uterine Cervical Neoplasms" OR "AlphaPapillomavirus" AND "Antiretroviral Therapy, Highly Active" limiting to English language literature. A total of 59 articles retrieved through this search were reviewed manually and additional articles were retrieved by cross referencing. The final analysis included 22 papers that are tabulated in Table 1 . We did not include studies that were not published as full manuscripts in peer-reviewed literature (e.g. conference abstracts or proceedings) or any unpublished or gray literature (e.g. project reports) to ensure inclusion of studies with completed (not interim) analyses.

\section{Results}

The published literature on this subject is striking in lack of standardization in study designs and methods of screening as well as the dearth of studies among populations from resource-limited settings. The differences in clinical versus population-based study designs, use of prevalent versus incident lesions as endpoints, different thresholds of diagnostic criteria for CIN, differing stan- 


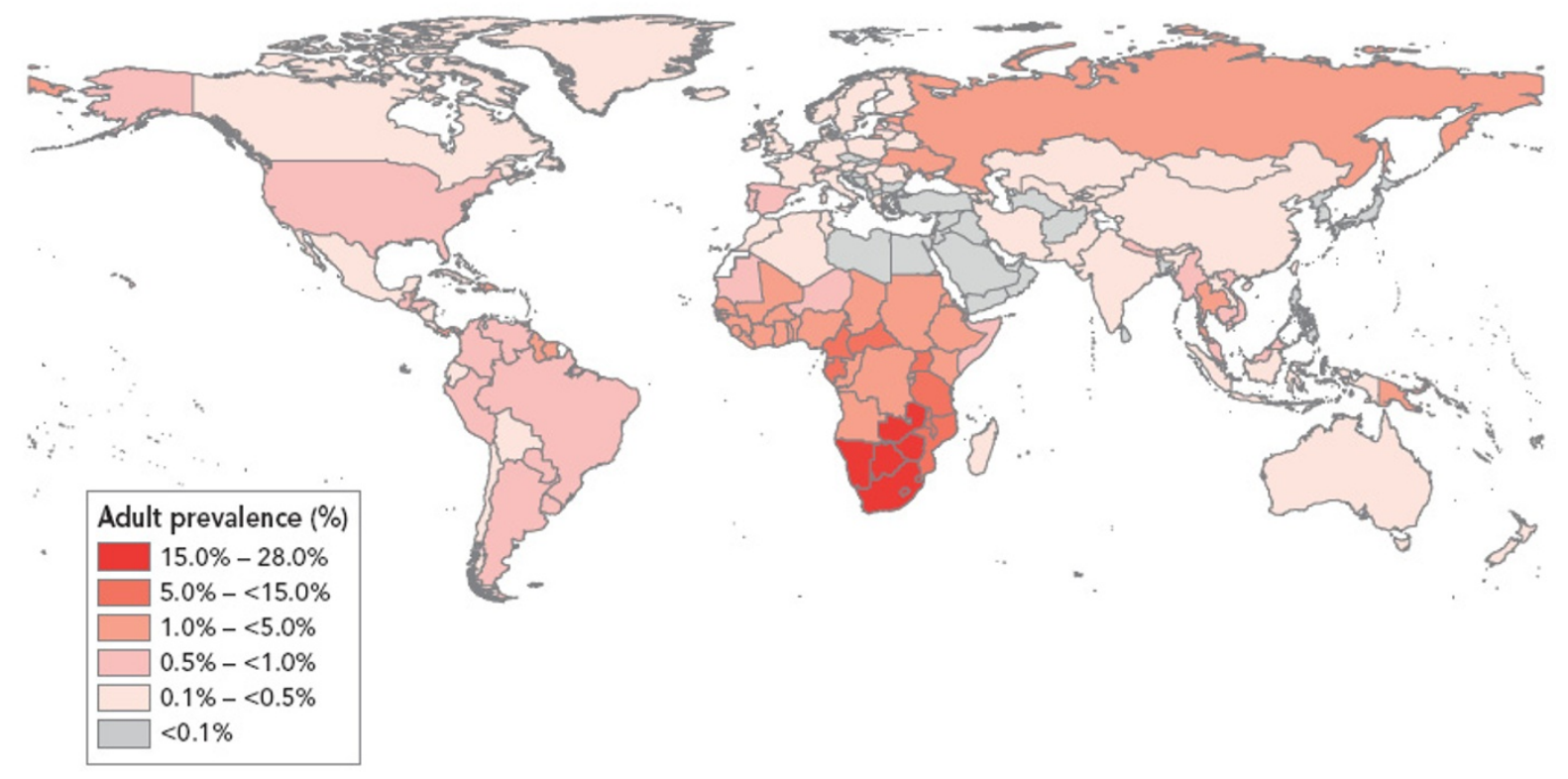

Figure 2 Global HIV prevalence (2007) [Source: UNAIDS http://www.unaids.org]

dards of lengths of follow-up evaluation periods, and nonuniform use of diagnostic assessments by colposcopy and/or histopathology make it difficult to draw overall conclusions about the impact of HAART on cervical disease. We discuss these differences by stage of HPV infection/cervical disease and highlight trends and similarities, as well as differences, in conclusions.

The definition of HAART also varies across studies, reflecting the evolution in terminology as well as the time horizon of adoption of newer classes of drugs over the past decade and a half. Several authors have defined HAART conventionally, i.e. as consisting of 2 nucleoside reverse transcriptase inhibitors (NRTIs) +1 protease inhibitor (PI) or 1 non-nucleoside reverse transcriptase inhibitor (NNRTI) [13-15]. Some referred to definitions of HAART prevalent at their institutions, [16-19] while others have listed multiple definitions in their work $[13,14,20,21]$. Since viral suppression and immune reconstitution appears to be dependent on the class of drug and duration of treatment, this is an important source of variation to be considered before drawing broad conclusions. Furthermore, in several studies, HAART use was measured by self-report. Some studies compared patient groups using HAART to groups using unspecified combinations of antiretroviral drugs $[17,20,22,23]$ while other studies have used antiretroviral-naïve patients in comparison groups[14,15]. CD4+ cell count has been uniformly used as a surrogate of immune status, with most studies controlling for CD4+ counts in the analysis $[15,17,20,23,24]$. Lower CD4+ cell counts have been shown to independently predict both incidence and progression of lesions, [25] and evidence of a dose-dependent relationship between $\mathrm{CD} 4+$ counts and regression of lesions has also been documented for women on HAART[13].

There are significant differences between studies in the utilization of the screening/diagnostic methods for cervical pathology. Most investigators have used cytological (Pap smear) changes with reporting based on the revised Bethesda classification, relying on low and high-grade squamous intraepithelial lesions (SIL) as endpoints. However, cervical cytology has only moderate clinical sensitivity (55\%-65\%) for detection of histopathologically confirmed 'true disease status' [18], and with low inter- or intraobserver'true correlation, even one grade of misclassification can result in highly distorted outcomes on incidence or regression, especially with varying thresholds of disease positivity. Very few studies report diagnosis of CIN by colposcopy and histopathology[20,26]. While most investigators have measured progression of cervical lesions independently, a prominent study has combined persistence and progression into one comparison group[14]. Researchers also differed in their treatment of atypical squamous cells of undetermined significance (ASCUS). Some considered a change of cytology result from low grade SIL (LSIL) to ASCUS as regression, [13] others resolved diagnoses of ASCUS with colposcopy and histology,[27] and still others left ASCUS diagnoses out of analysis[28]. 
Table 1: Description of included studies

\begin{tabular}{|c|c|c|c|c|}
\hline Author & Design & No. of women/cases & Country & HAART Definition \\
\hline Heard et al 1998 & Prospective Cohort & 533 & France & $2 \mathrm{NRTI}+1 \mathrm{PI}$ \\
\hline Heard et al 2002 & Prospective cohort & 168 & France & $\begin{array}{l}2 \text { NRTIs + } 1 \text { PI or } 1 \\
\text { NNRTI }\end{array}$ \\
\hline Heard et al 2006 & Prospective cohort & 289 & France & $\begin{array}{l}\text { as defined by French } \\
\text { National } \\
\text { Recommendations }\end{array}$ \\
\hline Orlando et al 1999 & Prospective cohort & 15 & USA & Undefined \\
\hline Moore et al 2002 & Prospective cohort & 71 & UK & Undefined \\
\hline Dorucci et al 2001 & Prospective cohort & 6 & Italy & NA \\
\hline Lillo et al 2001 & Prospective cohort & 168 & Italy & Undefined \\
\hline Del Mistro et al 2004 & Prospective cohort & 201 & Italy & $\begin{array}{l}1 \mathrm{PI}, 2 \text { NRTIs + NNRTI; } \\
\text { or } 3 \text { NRTIs }\end{array}$ \\
\hline Soncini et al 2007 & Prospective cohort & 101 & Italy & $\begin{array}{l}2 \text { NRTIs + } 1 \text { Pl, or } \\
\text { NNRTI; or } 3 \text { NRTIs }\end{array}$ \\
\hline Sirera et al 2007 & Retrospective cohort & 133 & Spain & $\begin{array}{l}2 \text { NRTIs + } 1 \text { PI or } 1 \\
\text { NNRTI }\end{array}$ \\
\hline Sirera et al 2008 & Retrospective cohort & 127 & Spain & $\begin{array}{l}2 \text { NRTIs + } 1 \text { PI or } 1 \\
\text { NNRTI }\end{array}$ \\
\hline Ellerbrock et al 2000 & Prospective cohort & 328 & USA & $\begin{array}{l}\text { Various NRTI and } \\
\text { NNRTI ( } 1 \text { or more in } \\
\text { combination) defined } \\
\text { by } 1997 \mathrm{NIH} \text { guidelines } \\
\text { or }>2 \mathrm{PI} \text { multiple } \\
\text { regimens defined }\end{array}$ \\
\hline Minkoff et al 2001 & $\begin{array}{l}\text { Prospective cohort, } \\
\text { WIHS }\end{array}$ & 781 & USA & \\
\hline $\begin{array}{l}\text { Ahdieh-Grant et al } \\
2004\end{array}$ & $\begin{array}{l}\text { Prospective cohort, } \\
\text { WIHS }\end{array}$ & 312 & USA & \\
\hline Schuman et al 2003 & $\begin{array}{l}\text { Prospective cohort, } \\
\text { HERS }\end{array}$ & 774 & USA & $\begin{array}{l}\text { as defined by DHHS } \\
\text { Guidelines }\end{array}$ \\
\hline Paramsothy et al 2009 & $\begin{array}{l}\text { Prospective cohort, } \\
\text { HERS }\end{array}$ & 537 & USA & $\begin{array}{l}\text { as defined by DHHS } \\
\text { Guidelines }\end{array}$ \\
\hline $\begin{array}{l}\text { Intl Collaboration on } \\
\text { HIV and Cancer } 2000\end{array}$ & $\begin{array}{l}\text { Meta-analysis of } \\
\text { prospective studies } \\
\text { evaluating cancer risk } \\
\text { in HIV-infected } \\
\text { persons }\end{array}$ & 36 & USA, Europe, Australia & NA \\
\hline Clifford et al 2005 & Prospective cohort & 6 & Switzerland & NA \\
\hline Engels et al 2006 & $\begin{array}{l}\text { HIV/AIDS Cancer } \\
\text { Match Study }\end{array}$ & 64 & USA & NA \\
\hline Biggar et al 2007 & $\begin{array}{l}\text { HIV/AIDS Cancer } \\
\text { Match Study }\end{array}$ & 55 & USA & NA \\
\hline Engels et al 2008 & $\begin{array}{l}\text { HIV/AIDS Cancer } \\
\text { Match Study }\end{array}$ & 28 & USA & NA \\
\hline Dal Maso et al 2009 & $\begin{array}{l}\text { HIV/AIDS Cancer } \\
\text { Match Study }\end{array}$ & 39 & Italy & NA \\
\hline
\end{tabular}


Our review covers studies that evaluate the effects of HAART on incidence, progression, and regression of HPV infection and CIN lesions/ICC. We only include studies among HIV-infected women which have controlled for cervical treatment to tease out the independent effect of HAART on recurrent lesions. We present salient features of studies grouped by impact of HAART on HPV infection, on CIN, and on ICC, in Tables 2, 3, 4, 5 and 6.

In the sections below, we discuss the salient study findings that highlight the heterogeneity in studies and the current dearth of evidence to definitively demonstrate the impact of HAART on HPV-associated cervical neoplastic disease in HIV-infected women.

\section{Studies on impact of HAART and Incidence, Prevalence and Clearance of HPV infection}

Studies that evaluate HPV infection have been limited, primarily because of limited availability of high quality $\mathrm{HPV}$ polymerase chain reaction (PCR) typing on cervical samples, while simultaneously evaluating the outcomes of cytological/colposcopic abnormalities over time among
HIV-infected women seeking HAART. (Table 2) In an Italian cohort study of $201 \mathrm{HIV}$-infected women followed for up to 6 years, antiretroviral therapy regimens were not associated with increased prevalence/persistence or regression of HPV infection[14]. Another Italian prospective cohort of $168 \mathrm{HIV}$-infected women also found no independent effect of receiving HAART with progression or regression of HPV infection, although higher and increasing CD4+ T-cell counts were associated with lower rates of HPV persistence[15]. This same study reported, however lower incidence of HPV-16 and 18 infections in women receiving HAART compared to women not on any treatment or women treated only with reverse transcriptase inhibitors (RTIs)[15]. A recent analysis from the HIV Epidemiology Research Study (HERS), a longitudinal multi-centric cohort of HIV-infected or atrisk HIV-uninfected women in the US, has also found an increased rate of HPV clearance among HIV-infected women on HAART who were diagnosed with SIL[23]. (Table 2) HAART did not have an impact on HIVinfected women with normal or ASCUS Pap results.

Table 2: Summary of studies analyzing the impact of ART on HPV incidence, persistence and clearance among HIVinfected women

\begin{tabular}{|c|c|c|c|c|c|}
\hline Author & Outcome & Follow-up & $\begin{array}{l}\text { Results } \\
\text { Comparison and } \\
\text { reference } \\
\text { groups }\end{array}$ & $\begin{array}{l}\text { Association } \\
(95 \% \mathrm{Cl}), p \text { value }\end{array}$ & Conclusion \\
\hline Lillo et al 2001 & $\begin{array}{l}\text { HPV PCR } \\
\text { biannually } \\
\text { Outcome: } \\
\text { Incidence or } \\
\text { Persistence (same } \\
\text { HPV genotype at } \\
\text { enrollment and } \\
\text { follow-up) }\end{array}$ & $\begin{array}{l}\text { Median } 15.4 \\
\text { months }\end{array}$ & $\begin{array}{l}\text { Incidence: HAART } \\
\text { vs. no therapy } \\
\text { Persistence: } \\
\text { HAART vs. no } \\
\text { therapy }\end{array}$ & $\begin{array}{l}\text { OR } 0.28(0.09- \\
0.86), p 0.02 \\
\text { OR } 1.18,(0.37- \\
3.77), p 0.77\end{array}$ & $\begin{array}{l}\text { HAART protective } \\
\text { against new HPV } \\
\text { infections } \\
\text { No impact of } \\
\text { HAART on } \\
\text { persistence }\end{array}$ \\
\hline $\begin{array}{l}\text { Del Mistro et al } \\
2004\end{array}$ & $\begin{array}{l}\text { HPV PCR every 6- } \\
12 \text { months } \\
\text { Outcome: } \\
\text { Persistence and } \\
\text { Clearance } \\
\text { (undefined) }\end{array}$ & $\begin{array}{l}49 \% \text { of } N \text { followed } \\
\text { for }>3 \text { years }\end{array}$ & $\begin{array}{l}\text { No odds ratios } \\
\text { discussed }\end{array}$ & -- & $\begin{array}{l}\text { "Prevalence and } \\
\text { clearance of HPV } \\
\text { not associated } \\
\text { with HAART" }\end{array}$ \\
\hline $\begin{array}{l}\text { Paramsothy et al } \\
2009\end{array}$ & $\begin{array}{l}\text { HPV PCR every } 6 \\
\text { months for } 10 \\
\text { visits, then } \\
\text { annually } \\
\text { Outcome: HPV } \\
\text { Clearance ( } 2 \\
\text { negative HPV PCR } \\
\text { tests at } \\
\text { consecutive visits) }\end{array}$ & $\begin{array}{l}\text { Median } 2 \text { years for } \\
\text { women on } \\
\text { HAART; } 2.7 \text { years } \\
\text { not on HAART }\end{array}$ & $\begin{array}{l}\text { HAART vs. no } \\
\text { HAART (adjusted } \\
\text { for CD4+ counts) } \\
\text { (i) in women with } \\
\text { LSIL or HSIL } \\
\text { (ii) in women with } \\
\text { ASCUS on } \\
\text { cytology } \\
\text { (iii) in women } \\
\text { with normal } \\
\text { cytology }\end{array}$ & $\begin{array}{l}\text { (i) HR } 4.5(95 \% \mathrm{Cl} \text { : } \\
1.216 .3) \\
\text { (ii) } \mathrm{HR} 1.0(95 \% \mathrm{Cl} \text { : } \\
0.4-2.5) \\
\text { (iii) HR } 1.7(95 \% \mathrm{Cl} \text { : } \\
0.9-3.1)\end{array}$ & $\begin{array}{l}\text { HAART promoted } \\
\text { clearance of HPV } \\
\text { infection in } \\
\text { women with LSIL } \\
\text { or HSIL on } \\
\text { cytology. } \\
\text { No impact of } \\
\text { HAART on women } \\
\text { with ASCUS } \\
\text { cytology No } \\
\text { impact of HAART } \\
\text { on women with } \\
\text { normal cytology }\end{array}$ \\
\hline
\end{tabular}


Table 3: Summary of studies analyzing the impact of ART on incidence of cervical disease among HIV-infected women

\begin{tabular}{|c|c|c|c|c|c|}
\hline Author & Outcome & Follow-up & $\begin{array}{l}\text { Results Comparison } \\
\text { and reference } \\
\text { groups }\end{array}$ & $\begin{array}{l}\text { Association } \\
(95 \% \mathrm{Cl}), \mathrm{p} \text { value }\end{array}$ & Conclusion \\
\hline Ellerbrock et al 2000 & $\begin{array}{l}\text { Histologically } \\
\text { confirmed SIL } \\
\text { cytology result }\end{array}$ & 3-12 month period & $\begin{array}{l}\text { ARV therapy vs. no } \\
\text { ARV therapy }\end{array}$ & $\begin{array}{l}\text { RR } 1.0(0.5-2.0), \\
\text { p } 0.94\end{array}$ & $\begin{array}{l}\text { ART has no impact on } \\
\text { incidence of SIL }\end{array}$ \\
\hline Schuman et al 2003 & Pap result of LSIL, HSIL & 4 years (median) & HAART vs. no HAART & $\begin{array}{l}\text { RR } 1.2(0.49-2.94), \\
p 0.7\end{array}$ & $\begin{array}{l}\text { HAART has no impact } \\
\text { on incidence of SIL }\end{array}$ \\
\hline Heard et al 2006 & $\begin{array}{l}\text { Pap change from } \\
\text { normal to LSIL or HSIL }\end{array}$ & 28 months (median) & HAART vs. no HAART & $\begin{array}{l}\mathrm{RR} 0.7(0.4-1.2), \\
p 0.15\end{array}$ & $\begin{array}{l}\text { HAART has no impact } \\
\text { on incidence of SIL }\end{array}$ \\
\hline Sirera et al 2007 & $\begin{array}{l}\text { Pap change from } \\
\text { normal to LSIL or HSIL } \\
\text { in all women on } \\
\text { HAART }\end{array}$ & Study period $1997-2005$ & $\begin{array}{l}\text { CD4+ }<200 \text { cells } / \mathrm{mm}^{3} \\
\text { vs. }>200 \text { cells } / \mathrm{mm}^{3} \text { (All } \\
\text { participants on } \\
\text { HAART) }\end{array}$ & $\begin{array}{l}\text { OR } 0.38(0.14-1.01) \\
p 0.05\end{array}$ & $\begin{array}{l}\text { HAART has no impact } \\
\text { on incidence of SIL }\end{array}$ \\
\hline Sirera et al 2008 & $\begin{array}{l}\text { Pap change from } \\
\text { normal to LSIL or HSIL }\end{array}$ & Study period $1997-2006$ & HAART vs. no HAART & $\begin{array}{l}\text { OR } 1.84(0.72-4.69), \\
p 0.20\end{array}$ & $\begin{array}{l}\text { HAART has no impact } \\
\text { on incidence of SIL }\end{array}$ \\
\hline Soncini et al 2007 & $\begin{array}{l}\text { Histologically } \\
\text { confirmed CIN }\end{array}$ & 11 years & $\begin{array}{l}\text { HAART vs. other NRTI } \\
\text { or no ARV therapy, } \\
\text { adjusted for CD4+ }\end{array}$ & $\begin{array}{l}\text { HR } 0.3(0.13-0.68), p \\
0.004\end{array}$ & $\begin{array}{l}\text { Only study showing } \\
\text { HAART prevents } \\
\text { incidence of CIN }\end{array}$ \\
\hline
\end{tabular}

In summary, the evidence about the impact of HAART on incidence, progression and clearance of HPV infection and lesions remains inconsistent and inconclusive. While these cohort studies are limited by their modest sample sizes in general, this limitation is especially significant when establishing impact on individual HPV types or phylogenetically similar types of HPV. It is expected that with improved techniques, expanded availability, and standardization of HPV primers that is being attempted at an international level, [29], future studies will be able to address these limitations. This will be even more important in the era of HPV vaccination targeted at high-risk HIV-infected women[30]. Yet, measurement of HPV infection is always confounded by the fact that most, if not all, detected HPV infections are transient, especially with the constantly fluctuating immunological milieu among HIV-infected women.

\section{Studies evaluating the impact of HAART on incidence of cervical lesions}

Since the goal of early detection (screening) for cervical cancer is to target precancerous lesions, studies that measure the impact of HAART on these lesions have significant implications for informing clinical practice as well as public health guidelines. Results from a pre-protease inhibitor-era cohort of HIV-infected women from the United States did not report a protective effect of antiretroviral treatment on SIL, even after controlling for CD4+ status and HPV-DNA status[31]. In a well-characterized French cohort with a median follow-up period of 28 months, there was no independent effect of receiving antiretroviral therapy or restored immune status (evi- denced by higher CD4+ T-cell counts) on incident SIL, which were significantly associated only with being in the 30-39 years age group[22]. In a retrospective analysis of a cohort from Spain of HIV-infected women with CD4+ cell counts $>350$ cells $/ \mathrm{mm}^{3}$ and with no previous SIL, there was no significant difference in SIL incidence between groups receiving versus not receiving HAART[28].

Similar findings are also reported from another Spanish cohort that indirectly assessed the impact of HAART on incidence of SIL as outcome on its effect on CD4+ T-cell counts or its effect on HIV-1 viral loads[24]. The HERS cohort results also report no decreased relative risk of incident SIL in HIV-infected women on HAART[25]. Only one prospective cohort study, following $101 \mathrm{HIV}$ infected women in Italy, has reported that being on HAART reduced SIL incidence as compared to not being on HAART, but was not able to distinguish the independent effect of HAART versus NRTI combination antiretroviral therapy on SIL incidence[20].

Thus, most published literature [22,24,25,28,32] (except one prospective cohort study [20]) suggests that being on HAART does not reduce the incidence of cervical precancerous lesions in HIV-infected women. (Table 3) While studies have been limited by the nature and duration of treatment regimens, there are other hypothesized explanations for this finding. SIL/CIN represent accumulative oncogenic changes in cells of the squamocolumnar junction of the cervix caused due to persistent HPV infections that may not be readily altered by the changing nature of immunological status induced in the short term by HAART. Additional evidence in this area will continue 
Table 4: Summary of studies analyzing the impact of ART on progression of cervical disease among HIV-infected women

\begin{tabular}{|c|c|c|c|c|c|}
\hline Author & Outcome & Follow-up & $\begin{array}{l}\text { Results } \\
\text { Comparison and } \\
\text { reference } \\
\text { groups }\end{array}$ & $\begin{array}{l}\text { Association } \\
(95 \% \mathrm{Cl}), \mathrm{p} \text { value }\end{array}$ & Conclusion \\
\hline Orlando et al 1999 & $\begin{array}{l}\text { Pap result lower } \\
\text { to higher grade } \\
\text { lesions }\end{array}$ & $\begin{array}{l}6 \text { months; } 114 \\
\text { days (median) }\end{array}$ & $\begin{array}{l}\text { CD4 }+<200 / \mathrm{mm}^{3} \\
\text { vs. CD4+ } \geq 200 / \\
\mathrm{mm}^{3} \text { (all women } \\
\text { on HAART) }\end{array}$ & $\begin{array}{l}\text { OR } 2.18(95 \% \mathrm{Cl} \\
\text { and } \mathrm{p} \text {-value not } \\
\text { reported) }\end{array}$ & $\begin{array}{l}\text { Unclear } \\
\text { (incomplete } \\
\text { reporting) }\end{array}$ \\
\hline $\begin{array}{l}\text { Schuman et al } \\
2003\end{array}$ & $\begin{array}{l}\text { Pap result of LSIL, } \\
\text { HSIL }\end{array}$ & 4 years (median) & HAART vs. no ART & $\begin{array}{l}\text { OR } 1.5(0.90- \\
2.49), p 0.12\end{array}$ & $\begin{array}{l}\text { HAART has no } \\
\text { impact on } \\
\text { progression of SIL }\end{array}$ \\
\hline $\begin{array}{l}\text { Paramsothy et al } \\
2009\end{array}$ & $\begin{array}{l}\text { Pap result: Normal } \\
\text { to ASCUS, ASCUS } \\
\text { to LSIL, LSIL to } \\
\text { HSIL }\end{array}$ & $\begin{array}{l}2 \text { years for women } \\
\text { on HAART, } 2.7 \\
\text { years not on } \\
\text { HAART }\end{array}$ & $\begin{array}{l}\text { HAART vs. no } \\
\text { HAART }\end{array}$ & $\begin{array}{l}\text { HR } 0.7(0.61 .0) \\
p>0.05\end{array}$ & $\begin{array}{l}\text { HAART has no } \\
\text { impact on } \\
\text { progression of SIL }\end{array}$ \\
\hline Lillo et al 2001 & $\begin{array}{l}\text { Pap result: Normal } \\
\text { to LSIL or HSIL and } \\
\text { LSIL to HSIL }\end{array}$ & $\begin{array}{l}15.4 \text { months } \\
\text { (median) }\end{array}$ & $\begin{array}{l}\text { HAART vs. no ART, } \\
\text { adjusted for CD4+ }\end{array}$ & $\begin{array}{l}\text { OR } 2.01(0.44- \\
9.20), p 0.36\end{array}$ & $\begin{array}{l}\text { HAART has no } \\
\text { impact on } \\
\text { progression of SIL }\end{array}$ \\
\hline $\begin{array}{l}\text { Del Mistro et al } \\
2004\end{array}$ & $\begin{array}{l}\text { Pap result: } \\
\text { "persistence or } \\
\text { worsening" }\end{array}$ & $\begin{array}{l}49 \% \text { followed for } \\
>3 \text { years }\end{array}$ & HAART vs. no ART & $\begin{array}{l}\text { 19/36 (53\%) } \\
\text { women vs. 8/16 } \\
(50 \%) \text { women, } \\
p \text { NR }\end{array}$ & $\begin{array}{l}\text { Unclear } \\
\text { (incomplete } \\
\text { reporting) }\end{array}$ \\
\hline Minkoff et al 2001 & $\begin{array}{l}\text { Pap result: Normal } \\
\text { to ASCUS, ASCUS } \\
\text { to LSIL, LSIL to } \\
\text { HSIL }\end{array}$ & $\begin{array}{l}6 \text { months: } \\
\text { consecutive } \\
\text { paired results on } \\
\text { each participant }\end{array}$ & $\begin{array}{l}\text { HAART vs. no } \\
\text { HAART, adjusted } \\
\text { for CD4+ and } \\
\text { initial Pap result }\end{array}$ & $\begin{array}{l}\text { OR } 0.68(0.52- \\
0.88), p \mathrm{NR}\end{array}$ & $\begin{array}{l}\text { Only study } \\
\text { showing evidence } \\
\text { that HAART } \\
\text { prevents } \\
\text { progression of SIL }\end{array}$ \\
\hline
\end{tabular}

to accrue through new studies that will follow-up HIVinfected women (many if not all without any initial presence of SIL/CIN) while comparing differences in duration needed for development of these lesions through active and periodic detecting incident SIL/CIN lesions.

\section{Studies evaluating the impact of HAART on progression of cervical lesions}

Studies evaluating the impact of HAART on progression of preexisting SIL have reported mixed results. (Table 4) Studies from the HERS cohort do not report an independent impact of HAART on progression of cervical lesions. A 2003 paper from HERS cohort reported that being on HAART was not an independent predictor of progression of SIL, although poorer immune status (reflected by CD $4+$ cell counts $<200 / \mathrm{mm}^{3}$ ) was associated with significantly higher odds of progression[25]. A more recent analysis from the same cohort found that women on HAART with SIL were $30 \%$ less likely to progress, but the difference was not statistically significant[23]. The two Italian cohorts discussed above also reported no significant difference in rates of progression between those treated with HAART compared to those not receiving any treatment $[14,15]$. However, a 2001 paper from the other well-characterized multicentric cohort in the
United States, the Woman's Interagency Health Study (WIHS), reported that HAART significantly decreased cytological progression even after controlling for CD4+ count and baseline Pap result [17] in a 6-month follow-up paired analysis (pair of consecutive visits). Cytological progression was less likely among those with lower HIV viral loads but was not associated with CD4+ status. Progression was more likely among those with persistent HPV infection.

Thus, data on impact of HAART on progression from low to higher grade SIL/CIN remains inconclusive with conflicting study results. While it is biologically possible that immune competence restored due to HAART may in fact prevent the progression, it appears more likely that progressive lesions are reflective of slow oncogenic changes due to persistent HPV infection that are possibly unaffected to the relatively short duration and typically moderate immunocompetence induced due to HAART. Comparison across studies is difficult since they differ in how they adjust for markers of immunological status of the patient (e.g. CD4+ counts, duration of being HIVinfected) as well as differences in HAART (e.g. duration of being on HAART, adherence and effectiveness of HAART). 
Table 5: Summary of studies analyzing the impact of ART on regression of cervical disease among HIV-infected women

\begin{tabular}{|c|c|c|c|c|c|}
\hline Author & Outcome & Follow-up & $\begin{array}{l}\text { Results } \\
\text { Comparison and } \\
\text { reference } \\
\text { groups }\end{array}$ & $\begin{array}{l}\text { Association } \\
(95 \% \mathrm{Cl})\end{array}$ & Conclusion \\
\hline Minkoff et al 2001 & $\begin{array}{l}\text { Pap result: Normal } \\
\text { to ASCUS, ASCUS } \\
\text { to LSIL, LSIL to } \\
\text { HSIL }\end{array}$ & $\begin{array}{l}\text { Variable follow- } \\
\text { up }\end{array}$ & $\begin{array}{l}\text { HAART vs. no } \\
\text { HAART, adjusted } \\
\text { for CD4+ and } \\
\text { initial Pap result }\end{array}$ & $\begin{array}{l}\text { OR } 1.4 \text { (1.04 - } \\
1.82), p \text { NR }\end{array}$ & $\begin{array}{l}\text { HAART has no } \\
\text { impact on } \\
\text { regression of SIL }\end{array}$ \\
\hline $\begin{array}{l}\text { Ahdieh - Grant et } \\
\text { al } 2004\end{array}$ & $\begin{array}{l}2 \text { consecutive } \\
\text { normal Pap } \\
\text { smears after LSIL } \\
\text { or HSIL }\end{array}$ & At least 7 years & $\begin{array}{l}\text { Regression rate in } \\
\text { person years; } \\
\text { HAART vs. no } \\
\text { HAART }\end{array}$ & $\begin{array}{l}12.5 \% \text { ( } 9.9 \text { - } \\
15.1 \%) \text { vs. } 0 \%, \text { OR/ } \\
\text { RR not reported }\end{array}$ & $\begin{array}{l}\text { Unclear } \\
\text { (incomplete } \\
\text { reporting) }\end{array}$ \\
\hline Heard et al 1998 & Pap result: SIL & 12 months & $\begin{array}{l}\text { Regression rate } \\
\text { (\%) in women on } \\
\text { triple-drug } \\
\text { HAART versus } \\
\text { those not on } \\
\text { HAART }\end{array}$ & $\begin{array}{l}35 \% \text { vs. } 12.5 \% \\
p 0.001\end{array}$ & $\begin{array}{l}\text { HAART promotes } \\
\text { regression of SIL }\end{array}$ \\
\hline Heard et al 2002 & $\begin{array}{l}\text { High grade CIN or } \\
\text { HSIL and low } \\
\text { grade CIN or LSIL } \\
\text { or normal. }\end{array}$ & $\begin{array}{l}17.7 \text { months } \\
\text { (median) }\end{array}$ & $\begin{array}{l}\text { HAART vs. no } \\
\text { HAART, adjusted } \\
\text { for CD4+ }\end{array}$ & $\begin{array}{l}\text { HR } 1.93 \text { (1.14 - } \\
3.29), p 0.01\end{array}$ & $\begin{array}{l}\text { HAART promotes } \\
\text { regression of SIL }\end{array}$ \\
\hline $\begin{array}{l}\text { Del Mistro et al } \\
2004\end{array}$ & $\begin{array}{l}\text { Pap result: } \\
\text { "persistence or } \\
\text { worsening" }\end{array}$ & $\begin{array}{l}49 \% \text { followed for } \\
>3 \text { years }\end{array}$ & HAART vs. no ART & $\begin{array}{l}\text { OR } 0.36(0.08- \\
1.62), p \mathrm{NR}\end{array}$ & $\begin{array}{l}\text { HAART has no } \\
\text { impact on } \\
\text { regression of SIL }\end{array}$ \\
\hline Moore et al 2002 & $\begin{array}{l}\text { High grade } \mathrm{CIN} \text { to } \\
\text { lower grade } \mathrm{CIN}\end{array}$ & $\begin{array}{l}10 \text { months } \\
\text { (median) } \\
\text { (IQR: } 8-14)\end{array}$ & $\begin{array}{l}\text { HAART naïve } \\
\text { versus HAART - } \\
\text { experienced }\end{array}$ & $\begin{array}{l}\text { OR } 1.9(0.28 \\
12.87), p 0.51\end{array}$ & $\begin{array}{l}\text { HAART has no } \\
\text { impact on } \\
\text { regression of SIL }\end{array}$ \\
\hline $\begin{array}{l}\text { Paramsothy et al } \\
2009\end{array}$ & $\begin{array}{l}\text { Pap result: Normal } \\
\text { to ASCUS, ASCUS } \\
\text { to LSIL, LSIL to } \\
\text { HSIL }\end{array}$ & $2-2.7$ years & $\begin{array}{l}\text { HAART vs. no } \\
\text { HAART }\end{array}$ & $\begin{array}{l}\text { HR } 1.3(1.0-1.7) \\
p>0.05\end{array}$ & $\begin{array}{l}\text { HAART has no } \\
\text { impact on } \\
\text { regression of SIL }\end{array}$ \\
\hline $\begin{array}{l}\text { Schuman et al } \\
2003\end{array}$ & $\begin{array}{l}\text { Pap result of LSIL, } \\
\text { HSIL }\end{array}$ & 4 years (median) & HAART vs. no ART & $\begin{array}{l}\text { OR } 0.86(0.50- \\
1.47), p 0.57\end{array}$ & $\begin{array}{l}\text { HAART has no } \\
\text { impact on } \\
\text { regression of SIL }\end{array}$ \\
\hline
\end{tabular}

Studies evaluating the impact of HAART on regression of cervical lesions

A 2001 report from the WIHS study concluded that women on ART who were infected with at least 1 highrisk HPV genotype were $40 \%$ more likely to experience regression of SIL than those not receiving ART, after adjustment for CD4+ cell counts and baseline cytology status[17]. The follow-up study report from the WIHS cohort found a regression rate of 12.5 per 100 person years among HAART recipients (significantly associated with lower post-HAART CD4+ counts) compared to no regression of lesions among HIV-infected women before HAART was introduced [13] Yet, this regression rate was five times lower than that of HIV negative women. The French cohort (discussed previously) reported first in 1998 and then in 2002 that women on HAART had 2-3 times the risk of regression than in women not on HAART[27,33]. A 2004 Italian study also found that the rate of regression of LSIL was higher among HAART recipients[14]. However, the findings from the HERS cohort suggests that regression of SIL is not independently associated with HAART status. In the 2003 report, SIL decreased by $22 \%$ for every $\log _{10}$ increase in HIV viral load, but this decline was not independently related to CD4+ counts or HAART status[25]. Also, although in the recent HERS analysis, while HIV-infected women on HAART were $30 \%$ more likely to exhibit regression on their cytology results than those not on HAART, this difference did not reach statistical significance[23]. Other studies have measured impact of surgical excisive treatment on recurrence of HPV-mediated cervical lesions, and correlated it with HAART status[34,35]. However, it is not possible to tease out the independent effect of HAART in such situations and hence we have not discussed these studies in our review. 
Table 6: HAART and Incidence of Invasive Cervical Cancer

\begin{tabular}{|c|c|c|c|c|c|}
\hline Author & Outcome & Design & $\begin{array}{l}\text { Results } \\
\text { Comparison and } \\
\text { reference } \\
\text { groups }\end{array}$ & $\begin{array}{l}\text { Association } \\
\text { measures and } \mathrm{Cl}\end{array}$ & Conclusion \\
\hline $\begin{array}{l}\text { Intl Collaboration } \\
\text { on HIV and Cancer } \\
2000\end{array}$ & $\begin{array}{l}\text { Cases of ICC in } \\
\text { multiple } \\
\text { population } \\
\text { studies }\end{array}$ & Meta-analysis & $\begin{array}{l}1997-1999 \text { (post- } \\
\text { HAART) vs. 1992- } \\
1996 \text { (pre-HAART) }\end{array}$ & $\begin{array}{l}\text { Adj IR } 2.1 \text { vs. 1.1; } \\
\text { RR } 1.87(99 \% \mathrm{Cl} \\
0.77-4.56)\end{array}$ & $\begin{array}{l}\text { Higher incidence } \\
\text { post HAART years, } \\
\text { but not stats. } \\
\text { significant }\end{array}$ \\
\hline Dorucci et al 2001 & $\begin{array}{l}\text { Cases of ICC in } \\
\text { Italian HIV } \\
\text { Seroconversion } \\
\text { Study }\end{array}$ & $\begin{array}{l}\text { Prospective } \\
\text { cohort/time- } \\
\text { series analysis }\end{array}$ & $\begin{array}{l}1996-1998 \text { (post- } \\
\text { HAART) vs. 1981- } \\
1995 \text { (pre-HAART) }\end{array}$ & $\begin{array}{l}\text { IR } 4.9 \text { vs. } 1.5 ; \mathrm{RH} \text { of } \\
\text { Incidence } 4.25 \\
(0.8-28.24)\end{array}$ & $\begin{array}{l}\text { Higher incidence } \\
\text { post HAART years, } \\
\text { but not stats. } \\
\text { significant }\end{array}$ \\
\hline Clifford et al 2005 & $\begin{array}{l}\text { Cases of ICC from } \\
\text { Swiss Cancer } \\
\text { Registry }\end{array}$ & $\begin{array}{l}\text { AIDS-Cancer } \\
\text { Match Study }\end{array}$ & $\begin{array}{l}\text { HAART vs. no } \\
\text { HAART }\end{array}$ & $\begin{array}{l}\text { SIR } 0 \text { vs. SIR 11.4; } \\
\text { RR not } \\
\text { estimatable }\end{array}$ & $\begin{array}{l}\text { Unclear } \\
\text { (incomplete } \\
\text { reporting) }\end{array}$ \\
\hline Engels et al 2006 & $\begin{array}{l}\text { Cases of ICC in } \\
\text { HIV/AIDS Cancer } \\
\text { Match Study }\end{array}$ & $\begin{array}{l}\text { AIDS-Cancer } \\
\text { Match Study }\end{array}$ & $\begin{array}{l}1996-2002 \text { (post- } \\
\text { HAART) vs. 1990- } \\
1995 \text { (pre-HAART) }\end{array}$ & $\begin{array}{l}\text { SIR } 5.3 \text { vs. SIR } 4.2 ; \\
\text { RR pr year: } 1.04 \\
(95 \% \text { Cl: } 0.94-1.15)\end{array}$ & $\begin{array}{l}\text { Higher incidence } \\
\text { post HAART years, } \\
\text { but not stats. } \\
\text { significant }\end{array}$ \\
\hline Biggar et al 2007 & $\begin{array}{l}\text { Cases of ICC in } \\
\text { HIV/AIDS Cancer } \\
\text { Match Study }\end{array}$ & $\begin{array}{l}\text { AIDS-Cancer } \\
\text { Match Study }\end{array}$ & $\begin{array}{l}\text { 1996-2002 (post- } \\
\text { HART) vs. 1990- } \\
1995 \text { (pre-HAART) }\end{array}$ & $\begin{array}{l}\text { IR } 86.5 \text { vs. } 64.2 ; \text { RR } \\
\text { of Incidence } 1.41 \\
(95 \% \mathrm{Cl} 0.81-2.46)\end{array}$ & $\begin{array}{l}\text { Higher incidence } \\
\text { post HAART years, } \\
\text { but not stats. } \\
\text { significant }\end{array}$ \\
\hline Engels et al 2008 & $\begin{array}{l}\text { Cases of ICC in } \\
\text { HIV/AIDS Cancer } \\
\text { Match Study }\end{array}$ & $\begin{array}{l}\text { AIDS-Cancer } \\
\text { Match Study }\end{array}$ & $\begin{array}{l}1996-2002 \text { (post- } \\
\text { HAART) vs. 1991- } \\
1995 \text { (pre-HAART) }\end{array}$ & $\begin{array}{l}\text { SIR } 2.9 \text { vs. } 3.1 \text {; RR } \\
0.8(95 \% \mathrm{Cl} 0.3- \\
2.0)\end{array}$ & $\begin{array}{l}\text { Lower incidence } \\
\text { post HAART years, } \\
\text { but not stats. } \\
\text { significant }\end{array}$ \\
\hline $\begin{array}{l}\text { Dal Maso et al } \\
2009\end{array}$ & $\begin{array}{l}\text { Cases of ICC in } \\
\text { Italian Cancer } \\
\text { Registries }\end{array}$ & $\begin{array}{l}\text { AIDS-Cancer } \\
\text { Match study }\end{array}$ & $\begin{array}{l}1997-2004 \text { (post- } \\
\text { HAART) vs. 1986- } \\
1996 \text { (pre-HAART) }\end{array}$ & $\begin{array}{l}\text { SIR } 41.5 \text { vs. } 51.0 \\
\text { RR not reported }\end{array}$ & $\begin{array}{l}\text { Lower incidence } \\
\text { in post HAART } \\
\text { years, but } \\
\text { conclusion } \\
\text { unclear } \\
\text { (incomplete } \\
\text { reporting) }\end{array}$ \\
\hline
\end{tabular}

Foot note to tables: Abbreviations:

ASCUS = atypical squamous cells of undetermined significance

$\mathrm{CD} 4+=\mathrm{CD} 4+\mathrm{T}$ lymphocyte count (cells $/ \mathrm{mm}^{3}$ )

DHHS = U.S. Department of Health and Human Services

HAART $=$ Highly active antiretroviral therapy

HERS = HIV Epidemiology Research Study

HIV = Human Immunodeficiency Virus

HPV = Human papillomavirus

$\mathrm{HR}=$ Hazard ratio

$\mathrm{HSIL}=$ high-grade squamous intraepithelial lesions

$\mathrm{ICC}=$ Invasive cervical cancer

$\mathrm{LSIL}=$ low-grade squamous intraepithelial lesions

NRTI = Nucleoside reverse transcriptase inhibitor

NNRTI = Non-nucleoside reverse transcriptase inhibitor

$\mathrm{NR}=$ Not reported

$\mathrm{OR}=$ Odds ratio

Pap = Papanicolaou smear

$\mathrm{PI}=$ Protease inhibitor

$\mathrm{RR}=$ Relative risk (rate ratio)

$\mathrm{SIR}=$ Standardized incidence ratio

WIHS = Women's Interagency HIV Study 
Thus, the evidence that HAART causes regression of lesions is also mixed just as the evidence about HAART on progression of lesions. In addition to the challenges in controlling for the markers of immune suppression and the type and nature of HAART, these cohort studies also differ by varying definitions of clinical endpoints of SIL/ CIN, possible misclassification of results, and the small sample sizes. Moreover, in the context of regression, the immunological and virological interplay between HIV, HPV, and HAART is not particularly well-understood. The pathways by which HIV may interact with HPV are still under investigation[36]. The HIV-1 tat gene has been shown to enhance HPV early gene expression, which is important in the cell transformation and the process of SIL development $[37,38]$. Some studies in HIV-infected women have also shown a decrease in vaginal Langerhans' cells, which promote local cervical cellular immunity $[39,40]$. Other mucosal cytokine factors have also been suggested as influencing local disease manifestation in HIV/HPV coinfection[41]. There is some limited invitro data to suggest that some HAART drugs, particularly protease inhibitors, may have an anti-tumor effect independent of increased immunocompetence, [42], although this has not been proven in clinical studies.

\section{Studies evaluating the impact of HAART on rates of invasive cervical cancer}

In 2000, the International Collaboration on HIV and Cancer pooled incidence estimates of ICC among all tilldate prospective cohort studies in North America, Europe, and Australia in the pre-HAART and postHAART eras. The study reports no difference in ICC incidence rates pre- or post HAART, although the pooled cases of ICC in the study were too few (36) to make definitive comparisons with the impact of HAART on other AIDS-associated cancers such d non-Hodgkin lymphoma[9]. The Italianas Kaposi's Seroconversion Study followed a prospective cohort of 483 women through pre and post-HAART eras found increased hazards of incidence of ICC in the post-HAART period but was also limited by the small sample size[10]. AIDS-Cancer Registry Matching studies have been attempted in both Europe (Italy, Switzerland) [19,21] and in the United States[11,12,16]. The data has revealed mixed evidence with some suggesting higher risk in the post-HAART era $[11,16]$ and others the opposite[12,19]. However, none of the reported associations in these studies are statistically significant, given their low absolute numbers of incident cases of invasive cervical cancer.

It has been suggested, however, that some record linkage methodologies may have underestimated the risks of some cancers among people withAIDS[43]. Thus, it is difficult to interpret the significance of these findings that suggest little change in the numbers of ICC between the pre- and post-HAART eras. Most authors also note the difficulty in comparing incidence of ICC across time due to competing mortality from other causes in HIVinfected women. Additionally, all these studies were conducted in industrialized settings, where the greater access to frequent cytological screening and early treatment services (rather than HAART) may have actually prevented ICC among the population of HIV-infected women.

\section{Gaps in evidence and directions for further research}

Evident in this review is that most research on the impact of HAART on cervical cancer has been conducted and reported from high-income nations while the developing world unquestionably shoulders a disproportionate burden of the morbidity and mortality associated with cervical cancer[1]. The same nations, especially those in Africa, also struggle with significant burden due to HIV/ AIDS, disproportionately affecting women $[44,45]$. The need for clear, evidence-based screening and treatment guidelines is especially imperative in these settings as hundreds of thousands of HIV-infected women are now accessing HAART and are starting to live longer in a moderately immunocompetent state. In these settings, a clearer understanding of the impact of HAART on cervical cancer in HIV-infected women is necessary not only from an academic and scientific perspective but also from a resource allocation and program implementation point of view. Prevention research in cervical cancer is often within the context of clinical care. Recent efforts through vertical HIV/AIDS care and treatment programs such as the U.S. President's Emergency Plan for AIDS Relief (PEPFAR) have started focusing on including cervical cancer screening as an integral component of HIV/AIDS care and treatment [46-48]. Newer screening methods such as HPV testing also need to be incorporated into more sensitive screening protocols for HIV-infected women[49,50].

Clearly, a trial randomizing women to HAART versus no HAART to study impact of HAART on incidence, progression or regression of HPV infection or CIN would be unethical. Yet, opportunities for answering these questions abound. It is quite feasible to nest outcomes research studies in HIV/AIDS care and treatment settings that may allow for accumulation of data in developing evidence-based guidelines for cervical cancer prevention in HIV-infected women. Some possible approaches to develop this evidence in the context of public health implementation programs and clinical, epidemiological, or implementation research studies could include:

\section{Nesting observational studies within pre-existing HIV- related study cohorts}

Dovetailing observational studies within pre-existing cohorts of HIV-infected women followed-up primarily 
for other HIV/AIDS related (non-cervical cancer) outcomes could be valuable. In many such cohort studies, especially those in middle incomes countries, data of varying degrees of completeness exists for cervical disease status (determined by cytology, visual inspectionbased screening, or colposcopy/histology) and HAART status for HIV-infected women. These data can be gainfully exploited for evaluating associations between the HAART and cervical neoplasia that may have context specific significance.

\section{Conducting quasi-experimental studies in HAART delivery settings}

In settings where HAART programs are being newly instituted, it may be possible to conduct innovative quasiexperimental studies to answer some important research questions. In these settings, a large proportion of HIVinfected women have never been screened for cervical cancer. By providing cervical cancer screening services through cost-effective and locally appropriate methods, it is possible to compare CIN disease status (baseline and follow-up) of cervical screening-naïve women who are initiating HAART newly and those who are HAART experienced for longer periods (e.g. $>6$ months). This design may provide valuable research opportunities without additional investments or formal randomization procedures for HAART exposure.

\section{Nesting studies within HIV-related randomized trials}

Multiple studies are underway evaluating the utility of early versus deferred initiation of HAART among HIVinfected persons [51,52]. Such studies provide ideal experimental venues for answering questions related to the degree of impact of HAART on HPV/cervical outcomes, especially considering that by design randomization would control for differences in HAART status in the two groups of women being compared.

\section{Sentinel surveys}

In settings with large numbers of women being treated with HAART, sentinel surveys can be conducted by documenting cervical disease status at predetermined frequencies and pre-determined sample sizes to assess changes in CIN outcomes over time. With careful data collection approaches and quality assurance measures, such sentinel sites will serve as important resources for monitoring disease trends over longer periods of time.

\section{Conclusion}

There remain significant challenges for elucidating the impact of ART on CIN disease outcomes. As evidenced in the review of studies above, the interactions between HIV, HPV, HAART and the development of cervical neoplasia are not clearly understood. Evidence of the impact of HAART on incidence, progression and regression of $\mathrm{CIN}$ is largely mixed. Given the small absolute numbers of invasive cervical cancer cases in HIV-infected women in industrialized nations, the role of HAART on ICC outcomes is difficult to determine with certainty. The reasons for the wide variation in the medical literature likely reflect complex immunological or viral-immune interactions yet to be elucidated. The heterogeneity of HPV and its ubiquity in populations, the difficulty in diagnosing CIN, and its long natural history may also play a role. Certainly, the biological interactions between HIV, HPV, and HAART appear different from other cancers of viral origins common in HIV-infected persons.

Innovative approaches are needed to elucidate the impact of HAART in HIV-infected women in resourcelimited settings. Given that the nature of this research is intertwined with clinical care, conduct of such epidemiology studies dovetailed within existing public health care and treatment programs for HIV-infected women can have significant patient benefits as well as provide insights to the interplay between two preventable diseases: AIDS and cervical cancer.

\section{Footnote to manuscript}

* Significant differences exist while describing the drug treatments for HIV

(antiretroviral therapy). In this article, we use the term highly active antiretroviral therapy (HAART) broadly in place of antiretroviral therapy (ART), although but most published literature only uses the terminology HAART to describe the more effective combination regimens introduced after 1996 and those currently recommended by the World Health Organization.

\section{Competing interests \\ The authors declare that they have no competing interests.}

\section{Authors' contributions}

VS conceived the manuscript idea and developed it along with LB. LB conducted the data abstraction. The manuscript was drafted by both LB and VS and both authors read and approved the final manuscript.

\section{Acknowledgements}

We thank Janeen Burlison, MSN, MPH and Carolyn Audet, PhD (both at the Institute for Global Health, Vanderbilt University School of Medicine in Nashville, TN) for valuable comments and inputs on a previous version of this manuscript.

Partial support for investigators was provided by NIH grants R21CA113465, D43TW001035, and UL1RR024975 to Vanderbilt University Medical Center.

\section{Author Details}

IInstitute for Global Health, Vanderbilt University School of Medicine, Nashville, USA and 2 Institute for Global Health and Department of Pediatrics, Vanderbilt University School of Medicine, Nashville, USA

Received: 29 July 2009 Accepted: 12 May 2010

Published: 12 May 2010

\section{References}

1. Parkin DM, Bray F, Ferlay J, Pisani P: Global cancer statistics, 2002. CA Cancer J Clin 2005, 55:74-108.

2. Hawes SE, Critchlow CW, Faye Niang MA, Diouf MB, Diop A, Toure P, Aziz Kasse A, Dembele B, Salif Sow P, Coll-Seck AM, et al.: Increased risk of high-grade cervical squamous intraepithelial lesions and invasive 
cervical cancer among African women with human immunodeficiency virus type 1 and 2 infections. J Infect Dis 2003, 188:555-563.

3. Massad LS, Seaberg EC, Watts DH, Minkoff H, Levine AM, Henry D, Colie C, Darragh TM, Hessol NA: Long-term incidence of cervical cancer in women with human immunodeficiency virus. Cancer 2009, 115:524-530.

4. Adam Y, van Gelderen CJ, de Bruyn G, McIntyre JA, Turton DA, Martinson NA: Predictors of persistent cytologic abnormalities after treatment of cervical intraepithelial neoplasia in Soweto, South Africa: a cohort study in a HIV high prevalence population. BMC Cancer 2008, 8:211.

5. Fife KH, Wu JW, Squires KE, Watts DH, Andersen JW, Brown DR: Prevalence and persistence of cervical human papillomavirus infection in HIVpositive women initiating highly active antiretroviral therapy. J Acquir Immune Defic Syndr 2009, 51:274-282.

6. Strickler HD, Burk RD, Fazzari M, Anastos K, Minkoff H, Massad LS, Hall C, Bacon M, Levine AM, Watts DH, et al:: Natural history and possible reactivation of human papillomavirus in human immunodeficiency virus-positive women. J Natl Cancer Inst 2005, 97:577-586.

7. Gingelmaier A, Grubert T, Kaestner R, Mylonas I, Weissenbacher T, Bergauer F, Barthell L, Friese K: High recurrence rate of cervical dysplasia and persistence of HPV infection in HIV-1-infected women. Anticancer Res 2007, 27:1795-1798.

8. Palefsky JM, Holly EA: Chapter 6: Immunosuppression and co-infection with HIV. J Nat/ Cancer Inst Monogr 2003:41-46.

9. Highly active antiretroviral therapy and incidence of cancer in human immunodeficiency virus-infected adults. J Nat/ Cancer Inst 2000, 92:1823-1830

10. Dorrucci M, Suligoi B, Serraino D, Tirelli U, Rezza G: Incidence of invasive cervical cancer in a cohort of HIV-seropositive women before and after the introduction of highly active antiretroviral therapy. J Acquir Immune Defic Syndr 2001, 26:377-380.

11. Engels EA, Pfeiffer RM, Goedert JJ, Virgo P, MCNeel TS, Scoppa SM, Biggar RJ: Trends in cancer risk among people with AIDS in the United States 1980-2002. AIDS 2006, 20:1645-1654.

12. Engels EA, Biggar RJ, Hall HI, Cross H, Crutchfield A, Finch JL, Grigg R, Hylton T, Pawlish KS, McNeel TS, Goedert JJ: Cancer risk in people infected with human immunodeficiency virus in the United States. Int $J$ Cancer 2008, 123:187-194.

13. Ahdieh-Grant L, Li R, Levine AM, Massad LS, Strickler HD, Minkoff H, Moxley M, Palefsky J, Sacks H, Burk RD, Gange SJ: Highly active antiretroviral therapy and cervical squamous intraepithelial lesions in human immunodeficiency virus-positive women. J Natl Cancer Inst 2004, 96:1070-1076

14. Del Mistro A, Bertorelle R, Franzetti M, Cattelan A, Torrisi A, Giordani MT, Sposetti R, Bonoldi E, Sasset L, Bonaldi L, et al:: Antiretroviral therapy and the clinical evolution of human papillomavirus-associated genital lesions in HIV-positive women. Clin Infect Dis 2004, 38:737-742.

15. Lillo FB, Ferrari D, Veglia F, Origoni M, Grasso MA, Lodini S, Mastrorilli E, Taccagni G, Lazzarin A, Uberti-Foppa C: Human papillomavirus infection and associated cervical disease in human immunodeficiency virusinfected women: effect of highly active antiretroviral therapy. J Infect Dis 2001, 184:547-551.

16. Biggar RJ, Chaturvedi AK, Goedert JJ, Engels EA: AIDS-related cancer and severity of immunosuppression in persons with AIDS. J Natl Cancer Inst 2007, 99:962-972.

17. Minkoff H, Ahdieh L, Massad LS, Anastos K, Watts DH, Melnick S, Muderspach L, Burk R, Palefsky J: The effect of highly active antiretroviral therapy on cervical cytologic changes associated with oncogenic HPV among HIV-infected women. AIDS 2001, 15:2157-2164.

18. Nanda K, McCrory DC, Myers ER, Bastian LA, Hasselblad V, Hickey JD, Matchar DB: Accuracy of the Papanicolaou test in screening for and follow-up of cervical cytologic abnormalities: a systematic review. Ann Intern Med 2000, 132:810-819.

19. Dal Maso L, Polesel J, Serraino D, Lise M, Piselli P, Falcini F, Russo A, Intrieri $T$, Vercelli M, Zambon P, et al.: Pattern of cancer risk in persons with AIDS in Italy in the HAART era. Br J Cancer 2009, 100:840-847.

20. Soncini E, Zoncada A, Condemi V, Antoni AD, Bocchialini E, Soregotti P. Reduction of the risk of cervical intraepithelial neoplasia in HIVinfected women treated with highly active antiretroviral therapy. Acta Biomed 2007, 78:36-40.

21. Clifford GM, Polesel J, Rickenbach M, Dal Maso L, Keiser O, Kofler A, Rapiti $E$, Levi F, Jundt G, Fisch T, et al.: Cancer risk in the Swiss HIV Cohort Study: associations with immunodeficiency, smoking, and highly active antiretroviral therapy. J Nat/ Cancer Inst 2005, 97:425-432.

22. Heard I, Potard V, Costagliola D: Limited impact of immunosuppression and HAART on the incidence of cervical squamous intraepithelial lesions in HIV-positive women. Antivir Ther 2006, 11:1091-1096.

23. Paramsothy P, Jamieson DJ, Heilig CM, Schuman PC, Klein RS, Shah KV, Rompalo AM, Cu-Uvin S, Duerr A: The effect of highly active antiretroviral therapy on human papillomavirus clearance and cervical cytology. Obstet Gynecol 2009, 113:26-31.

24. Sirera G, Videla S, Lopez-Blazquez R, Llatjos M, Tarrats A, Castella E, Grane $\mathrm{N}$, Alcalde C, Tural C, Rey-Joly C, Clotet B: Evolution of cervical cytologic changes among HIV-infected women with normal cytology in the HAART era. AIDS Res Hum Retroviruses 2007, 23:965-971.

25. Schuman P, Ohmit SE, Klein RS, Duerr A, Cu-Uvin S, Jamieson DJ, Anderson J, Shah KV: Longitudinal study of cervical squamous intraepithelial lesions in human immunodeficiency virus (HIV)seropositive and at-risk HIV-seronegative women. J Infect Dis 2003, 188:128-136

26. Moore AL, Sabin CA, Madge S, Mocroft A, Reid W, Johnson MA: Highly active antiretroviral therapy and cervical intraepithelial neoplasia. AIDS 2002, 16:927-929.

27. Heard I, Tassie JM, Kazatchkine MD, Orth G: Highly active antiretroviral therapy enhances regression of cervical intraepithelial neoplasia in HIV-seropositive women. AIDS 2002, 16:1799-1802.

28. Sirera G, Videla S, Lopez-Blazquez R, Llatjos M, Tarrats A, Castella E, Grane $\mathrm{N}$, Tural C, Rey-Joly C, Clotet B: Highly active antiretroviral therapy and incidence of cervical squamous intraepithelial lesions among HIVinfected women with normal cytology and CD4 counts above 350 cells/mm3. J Antimicrob Chemother 2008, 61:191-194.

29. Ferguson M, Wilkinson DE, Zhou T: WHO meeting on the standardization of HPV assays and the role of the WHO HPV Laboratory Network in supporting vaccine introduction held on 24-25 January 2008, Geneva, Switzerland. Vaccine 2009, 27:337-347.

30. Palefsky J: Human papillomavirus infection in HIV-infected persons. Top HIV Med 2007, 15:130-133.

31. Ellerbrock TV, Chiasson MA, Bush TJ, Sun XW, Sawo D, Brudney K, Wright TC Jr: Incidence of cervical squamous intraepithelial lesions in HIVinfected women. Jama 2000, 283:1031-1037.

32. Walboomers JM, Jacobs MV, Manos MM, Bosch FX, Kummer JA, Shah KV Snijders PJ, Peto J, Meijer CJ, Munoz N: Human papillomavirus is a necessary cause of invasive cervical cancer worldwide. J Pathol 1999, 189:12-19.

33. Heard I, Schmitz V, Costagliola D, Orth G, Kazatchkine MD: Early regression of cervical lesions in HIV-seropositive women receiving highly active antiretroviral therapy. AIDS 1998, 12:1459-1464.

34. Heard I, Potard V, Foulot H, Chapron C, Costagliola D, Kazatchkine MD: High rate of recurrence of cervical intraepithelial neoplasia after surgery in HIV-positive women. J Acquir Immune Defic Syndr 2005, 39:412-418.

35. Robinson WR, Hamilton CA, Michaels SH, Kissinger P: Effect of excisional therapy and highly active antiretroviral therapy on cervical intraepithelial neoplasia in women infected with human immunodeficiency virus. Am J Obstet Gynecol 2001, 184:538-543,

36. Meys R, Gotch FM, Bunker CB: Human papillomavirus in the era of highly active antiretroviral therapy for human immunodeficiency virus: an immune reconstitution-associated disease? Br J Dermatol 2009.

37. Vernon SD, Hart CE, Reeves WC, Icenogle JP: The HIV-1 tat protein enhances E2-dependent human papillomavirus 16 transcription. Virus Res 1993, 27:133-145.

38. Tornesello ML, Buonaguro FM, Beth-Giraldo E, Giraldo G: Human immunodeficiency virus type 1 tat gene enhances human papillomavirus early gene expression. Intervirology 1993, 36:57-64.

39. Spinillo A, Tenti P, Zappatore R, De Seta F, Silini E, Guaschino S: Langerhans' cell counts and cervical intraepithelial neoplasia in women with human immunodeficiency virus infection. Gynecol Oncol 1993, 48:210-213

40. Olaitan A, Johnson MA, MacLean A, Poulter LW: The distribution of immunocompetent cells in the genital tract of HIV-positive women. AIDS 1996, 10:759-764

41. Nicol AF, Nuovo GJ, Salomao-Estevez A, Grinsztejn B, Tristao A, Russomano F, Lapa ESJR, Oliveira MP, Pirmez C: Immune factors involved 
in the cervical immune response in the HIV/HPV co-infection. $J$ Clin Pathol 2008, 61:84-88.

42. Monini P, Sgadari C, Toschi E, Barillari G, Ensoli B: Antitumour effects of antiretroviral therapy. Nat Rev Cancer 2004, 4:861-875.

43. Deapen D, Cockburn M, Pinder R, Lu S, Wohl AR: Population-based linkage of AIDS and cancer registries: importance of linkage algorithm. Am J Prev Med 2007, 33:134-136.

44. Lopez AD, Mathers CD: Measuring the global burden of disease and epidemiological transitions: 2002-2030. Ann Trop Med Parasitol 2006, 100:481-499.

45. Abdool Karim SS, Abdool Karim Q, Gouws E, Baxter C: Global epidemiology of HIV-AIDS. Infect Dis Clin North Am 2007, 21:1-17. vii.

46. Mwanahamuntu MH, Sahasrabuddhe VV, Pfaendler KS, Mudenda V, Hicks ML, Vermund SH, Stringer JS, Parham GP: Implementation of 'see-andtreat' cervical cancer prevention services linked to HIV care in Zambia. AIDS 2009, 23:N1-5.

47. Pfaendler KS, Mwanahamuntu MH, Sahasrabuddhe VV, Mudenda V, Stringer JS, Parham GP: Management of cryotherapy-ineligible women in a "screen-and-treat" cervical cancer prevention program targeting HIV-infected women in Zambia: lessons from the field. Gynecol Oncol 2008, 110:402-407.

48. Mwanahamuntu MH, Sahasrabuddhe VV, Parham GP: HPV screening for cervical cancer in rural India. N Engl J Med 2009, 361:305. author reply 306.

49. Womack SD, Chirenje ZM, Gaffikin L, Blumenthal PD, McGrath JA, Chipato T, Ngwalle S, Munjoma M, Shah KV: HPV-based cervical cancer screening in a population at high risk for HIV infection. Int J Cancer 2000, 85:206-210.

50. Franceschi S, Jaffe H: Cervical cancer screening of women living with HIV infection: a must in the era of antiretroviral therapy. Clin Infect Dis 2007, 45:510-513.

51. Questions and Answers: The CIPRA HT001 Clinical Trial [http:// www3.niaid.nih.gov/news/QA/CIPRA HT01 ga.htm]

52. HPTN 052: A Randomized Trial to Evaluate the Effectiveness of Antiretroviral Therapy Plus HIV Primary Care versus HIV Primary Care Alone to Prevent the Sexual Transmission of HIV-1 in Serodiscordant Couples [http://www.hptn.org/research studies/hptn052.asp]

doi: 10.1186/1750-9378-5-8

Cite this article as: Bratcher and Sahasrabuddhe, The impact of antiretroviral therapy on HPV and cervical intraepithelial neoplasia: current evidence and directions for future research Infectious Agents and Cancer 2010, 5:8

Submit your next manuscript to BioMed Centra and take full advantage of:

- Convenient online submission

- Thorough peer review

- No space constraints or color figure charges

- Immediate publication on acceptance

- Inclusion in PubMed, CAS, Scopus and Google Scholar

- Research which is freely available for redistribution

Submit your manuscript at www.biomedcentral.com/submit
C Biomed Central 